\title{
Development of Integrated Analysis Practicum Module based on Green Chemistry
}

\author{
Army Auliah \\ Universitas Negeri Makassar \\ Makassar, Indonesia
}

\author{
Mulyadi \\ Universitas Negeri Makassar \\ Makassar, Indonesia
}

\author{
Muharram \\ Universitas Negeri Makassar \\ Makassar, Indonesia
}

\begin{abstract}
This study aimed to develop a module practicum of chemistry analysis integrated-based on green chemistry to improve environmental the attitude of students which is valid and efficient. The four-step of the plump model adopted was used in the development of the module. These stages are the initial assessment phase, the planning stage, the stage of realisation/construction and implementation phase. The first three steps are used to develop and validate the module, while the last step is used to measure the effectiveness of the module. The module contains three main part, namely introduction, learning activity and bibliography. The introduction to the module containing a general explanation, the general objectives of learning, and the specific goals of learning. Learning activities section contains descriptions of learning contents, summaries, test, answer key, and feedback. A validation test was submitted to two green chemistry experts, two pedagogic experts, and one environment expert. The effectiveness of the module has been carried out by giving learning achievement test and observe environment attitude of a group of 25 students. The test of learning achievement cover attitude of the environment. Results of this study show that the module has a valid category with 3.2 scores. The average learning achievement and environment attitude of the students increase from score 6.45 to 18.29 of score total 22 and from $40.66 \%$ to $65.97 \%$, respectively. Those are related to the effectiveness of the module.
\end{abstract}

Keywords-Module practicum; integrated chemical analysis; green chemistry; attitude of environment

\section{INTRODUCTION}

Green chemistry can be used as the primary means to design and improve the learning process to realise sustainable development. Sustainable development is development in three key areas of economic, environmental, and social [1].

Sustainable development in the field of environmental education has been attempted on any sector of the development, including education. The efforts are being made in the area of chemistry when people began to realise the effects of the use of DDT on birds, hydrochloric compounds and heavy metals by industrial waste cause cancer epidemic for children around the plant, and some of the impact caused by products and other chemicals. Also, this research led to an emphasis on the development of production processes that reduce and even eliminate the use of hazardous materials or the creation, also in designing, producing, and applying chemical products. The emphasis on this effort that became known as the Green Chemistry [2].
There are twelve principles of Green Chemistry[3]. The principle began by preventing the occurrence of waste in the process followed by the designing safe chemical products. The next principle is designing a safe synthesis process, using renewable raw materials, and using a catalyst. The principle also includes the avoidance of derivatisation and temporary modification in chemical reactions. The other principles are maximized economic atoms, use a safe solvent, improve energy efficiency in response, designing chemicals that are easily degraded, use of direct analytical methods to reduce pollution, and minimize potential accidents.

Emphasis creation of green chemistry has been attempted, but have not reaped the results as expected. Various phenomena of environmental crisis can be found everywhere. That ecological crisis is caused by the presence of industry in the surrounding area. Industrial waste management with either one of the principles of green chemistry can only be done by the competent authority and understanding of waste generated, as well as its impacts. That understanding led to the parties involved will certainly have awareness and responsibility in disposing of waste, especially to streams or lakes. Their moral responsibility you have, the parties concerned process the waste before it dumped into the river. For it is certainly needed an effort to make practitioners and industry workers better understand the treatment of sewage. Attempts to do the formal state of learning relating to green chemical or chemicals that are environmentally friendly. This is by the opinion [4] that education is essential in popularising green chemistry.

One of the vocational School in South Sulawesi, Indonesia, is SMAK Makassar, SMK-SMAK. It is a vocational school whose mission is to prepare the human resources industry in the field of analytical chemistry midlevel productive, skilled, independent and insightful entrepreneurs to fill the jobs by their fields to accelerate and strengthen the growth of the industry with a view to supporting national development. The mission shows that alumni are intended for industrial or other areas related to science, the especially chemistry chemical analyst.

SMK-SMAK's Students study chemistry in the classroom and the laboratory is every day. Learning in the lab using the guidelines to implement practicum called modules. Moreover, lab module which they have been doing has not integrated the concept or paradigm of green chemistry. Teachers assume green chemistry is lack of contribution to learning chemistry. 
As a result, students are also not accustomed to applying green chemistry when working in the laboratory.

After 23 years of green chemistry was introduced with the aim of protecting the environment [5], but teachers as well students have not applied yet. Also, the IUPAC and UNESCO have proclaimed the year 2011 as the International chemical that emphasis to the contribution of education to sustainable development [6]. The emphasis absolute because he thinks there is practically no sustainability education at most schools and universities curriculum. Under these conditions, the researchers found it necessary to develop experimental module-based Green Chemistry. Twelve principles of green chemistry can be applied in the field or the world of work. It is a complement to the school curriculum that considers the concept of sustainability.

\section{RESEARCH METHOD}

\section{A. Type of Research}

This study is a Research and Development (R\&D) model, which is aimed to develop a module Practicum of Chemistry Analysis Integrated consideration the principles of green chemistry. Data were analyzed using descriptive statistics to describe the results of the expert assessment of the module practicum and learning outcomes and student learning activities.

\section{B. Development Practicum Module of Integrated Chemistry Analysis}

The design of the development is done through four phases according to the development model of [7], as explained below.

1) Define: This stage includes the following principal steps leading analysis aims to set the basic problem faced in learning chemistry at SMK-SMAK especially on practicum.

2) Design: This phase seeks to produce draft learning devices, namely lab module. This phase consists of four steps: (a) Election of Practical Module format, (b) An initial draft Module Practicum, (c) Preparation of an essay test to measure the achievement of competency and attitude of the loving environment is expected.

3) Development Phase: This phase is to produce Practical Analysis Module Integrated into sub subject Analysis of Food Ingredients revised based on suggestions from experts.

4) Disseminate: This phase is the phase of use of modules that have been developed. This stage is the stage of limited testing at a lab class.

\section{Research Instruments and Data collection}

The researchers provided practicum module to the experts to be assessed by advising against such modules to obtain valid module. The researchers also provided test results to learn to know the results of students' cognitive learning and knowledge of green chemistry. Besides, the researchers conducted a behavioural observation of green chemistry by giving some green chemistry behavioural criteria that appear in each phase of practicum. Observation sheet filled in by the observers during the practicum takes place.

\section{RESULT AND DISCUSSION}

The learning is a process that makes people, or living thing is studying. In other words, learning is the effort made to place the process of learning. In the context of formal teaching and learning in the classroom, the study was an attempt by teachers so that students can learn, [8]. Learning is a teaching and learning activities from the point of student activity in the form of students' learning experiences, namely the student activities planned by the teacher to be experienced by students during learning activities take place [9]. Teaching and learning activities can be done both in the classroom and in the laboratory. Learning in the laboratory is an absolute do for learning science, including chemistry.

Currently, learning chemistry requires a new paradigm known as green chemistry [10].Green chemistry is a contributor to sustainable development [11] refer to it as a sustainable chemistry. Something similar was stated by [12] that the chemical sciences play a role in education towards sustainable development.

Learning chemistry at laboratory through experiments on chemical reaction is a medium to apply the twelve principles of Green Chemistry. This research allows for doing the experiment activities that require students to apply the principles of green chemistry. The integration of green chemistry in teaching chemistry in the laboratory also increase students' knowledge about sustainability. The same is expressed by [13]that "the Green chemistry has enhanced students' understanding of both TECs (Traditional Environmental Concepts) and SDCs (Sustainable Development Concepts). It shows that the concept of green chemistry needs to be integrated into learning chemistry in the laboratory using the learning media that can be a module practicum.

The module of green chemistry practicum was developed concerning the lesson study model. According to [3], that the learning model must meet the following elements: 1. Syntax, i.e. the operational steps of learning; 2. The social system, i.e. the atmosphere and norms that apply in learning; 3 . The principle of reaction, which is to describe how teachers view, treat and respond to students; 4. The support system that is all means, materials, tools or learning environment that supports learning; 5. Instructional impact, i.e. learning outcomes obtained directly based on measurable objectives (instructional effects) and out-of-target outcomes (nurturant effects).

Module practicum of Chemistry Analysis Integrated-Based on Green Chemistry resulting from this research is valid based on the validation of five experts. This module contains materials lab analysis of foodstuffs which is a sub-unified subject of Chemistry Analysis Integrated. In each experiment integrated green chemistry paradigm corresponding to the 12 principles of green chemistry. It is intended that the students continue to apply the principles of green chemistry in carrying out lab as proposed by [14] "concept of Green Chemistry needs to be implemented in the chemistry learning in schools 
and universities, especially in practical activities in the laboratory".

The result of observations during the chemistry practicum learning process was carried out showing various behavioural changes of the students (Table 1).

TABLE I. OBSERVED CHANGES IN STUDENT ATTITUDES BASED ON GREEN CHEMICAL PRINCIPLES

\begin{tabular}{|l|l|l|}
\hline \multicolumn{1}{|c|}{$\begin{array}{c}\text { Green Chemistry } \\
\text { Principles }\end{array}$} & \multicolumn{2}{|c|}{ The application of Green Chemistry Module } \\
\cline { 2 - 4 } $\begin{array}{l}\text { Prevention of } \\
\text { Pollution }\end{array}$ & $\begin{array}{l}\text { The remainder of the } \\
\text { solution is discharged } \\
\text { directly into the drains }\end{array}$ & $\begin{array}{l}\text { The remainder of the } \\
\text { solution is } \\
\text { accommodated in a } \\
\text { container for disposal } \\
\text { in a safe place }\end{array}$ \\
\hline Raw material savings & $\begin{array}{l}\text { Uncontrolled use of } \\
\text { chemicals }\end{array}$ & $\begin{array}{l}\text { Saving of chemical } \\
\text { usage. }\end{array}$ \\
\hline Energy efficiency & $\begin{array}{l}\text { Electrical equipment is } \\
\text { powered on } \\
\text { continuously }\end{array}$ & $\begin{array}{l}\text { The equipment is } \\
\text { turned on when it will } \\
\text { be used use }\end{array}$ \\
\hline $\begin{array}{l}\text { Minimize } \\
\text { accidents }\end{array}$ & $\begin{array}{l}\text { Students do not unts use safety } \\
\text { safety equipment. } \\
\text { equipment } \\
\text { protective work such } \\
\text { as masks and gloves }\end{array}$ \\
\hline
\end{tabular}

Applications Green Chemistry principles in the lab will foster students' attitudes loving environment. This is evident from the results of this study, namely observation of student activity associated with green chemistry increased from $40.66 \%$ to $65.97 \%$. Also, the learning outcomes of students also increased from 6.45 to 18.29 , which means that students' attitudes to the environment are also increased by the growth of learning outcomes because the learning achievement test involve test that is related to green chemistry.

\section{CONCLUSION}

Learning chemistry in the laboratory requires learning media in the form of instructions to experiment. The Directive is packaged in a lab module that integrates the concept of green chemistry on each trial. This research showed that students could practice the twelve principles of green chemistry as a form of self- environment. The use of chemical lab module integrated analysis based green chemistry is increased in both learning outcomes, and student attitudes are loving the environment.

\section{REFERENCES}

[1] A. Vilches and D. Gil-Pérez, "Creating a Sustainable Future: Some Philosophical and Educational Considerations for Chemistry Teaching," Sci. Educ., vol. 22, no. 7, pp. 1857-1872, 2013.

[2] J.. Steinfeld, "Book Reviews," J. Ind. Ecol., pp. 145-147, 2000.

[3] J. Isac-García, J. A. Dobado, F. G. Calvo-Flores, and H. MartínezGarcía, Experimental Organic Chemistry: Laboratory Manual. Elsevier Science, 2015.

[4] W. Wardencki, J. Curylo, and J. Namiesnik, "Green chemistry-current and future issues," Polish J. Environ. Stud., vol. 14, no. 4, pp. 389-395, 2005.

[5] J. Clark, R. Sheldon, C. Raston, M. Poliakoff, and W. Leitner, "5 years of Green Chemistry," Green Chem., vol. 16, pp. 18-23, 2014.

[6] G. V Shultz et al., "Creating a Sustainable Future: Some Philosophical and Educational Considerations for Chemistry Teaching," J. Chem. Educ., vol. 8, no. 3, pp. 1857-1872, 2015.

[7] J. van den Akker, B. Brenda, A. E. Kelly, N. Nieveen, and T. Plomp, Educational Design Research. Netherlands: SLO. Netherlands Institute for Curriculum Development, 2013.

[8] R. I. Arends, Learning to Teach, Fifth Edit. Singapore: Mc. Graw Hill., 2001 .

[9] M. Karpudewan, W. M. Roth, and D. Sinniah, "The Role of Green Chemistry Activities in Fostering Secondary School Students' Understanding of Acid-Base Concepts and Argumentation," Chem. Educ. Res. Pract., vol. 17, pp. 893-901, 2016.

[10] P. T. y I. J. Anastas and I. . Levy, "Green Chemistry Education: Changing the course of Chemistry," ACS Symp. Ser. 1011., pp. 1-18, 2009.

[11] M. K. Juntunen and M. K. Aksela, "Education for sustainable development in chemistry - Challenges, possibilities and pedagogical models in Finland and elsewhere," Chem. Educ. Res. Pr. J. Name, vol. 0, pp. 1-3, 2014.

[12] M. Burmeister, F. Rauch, and I. Eilks, "Education for Sustainable Development (ESD) and chemistry education," Chem. Educ. Res. Pract., vol. 13, p. 59, 2012.

[13] M. Karpudewan, Z. H. Ismail, and N. Mohamed, "The integration of green chemistry experiments with sustainable development concepts in pre-service teachers' curriculum: Experiences from Malaysia," Int. J. Sustain. High. Educ., vol. 10, no. 2, pp. 118-135, 2009.

[14] A. Hofstein and Mamlok-Naaman, "The laboratory in science education: the state of the art," Chem. Educ. Res. Pract., vol. 8, no. 2, pp. 105-107, 2007. 